\title{
East Asian Regionalism and South Korea's FTA Strategy"
}

Young Jong Choi

(Catholic University)

\section{$\langle$ Content}

I. Introduction

П. Current State of East Asian

Regionalism
III. South Korea's FTA Strategy

IV. Conclusion

- Key Words: FTA, East Asian regionalism, FTA partners, power, income-level

\section{【ABSTRACT 】}

This paper is an attempt to assess the current state of East Asian regionalism and draw South Korea's strategy toward East Asian regional integration in general and bilateral FTAs in particular. This paper provides an analytical framework to evaluate FTA partners, upon which the South Korean government can design a FTA strategy. Income level and relative power of FTA partners are the two independent variables that determine the nature of the FTA agreement. This paper concludes that South Korea will get the maximum benefits by forming FTA with advanced, powerful economies like Japan and the United States. This paper cautions the South Korean government not to rush in for a FTA with China, a developing major power. This paper also suggests that liberalizing domestic reforms are imperative to South Korea's economic revival irrespective of it's strategy toward FTA or regional integration.

\footnotetext{
* This study was supported by the Research Fund 2004 of the Catholic University of Korea.
} 


\section{Introduction}

Regionalism is a global phenomenon. Almost every member of the World Trade Organization (WTO) joins at least one regional trading arrangement. Even East Asia, which existed outside this global trend for a long time, is actively seeking regionalism of its own, particularly following the financial crisis of 1997. East Asia is now more identified as a region, whose membership includes ten ASEAN members plus three Northeast Asian countries, China, Japan, and South Korea. This ASEAN plus Three (APT) process is making progress as an umbrella organization in East Asia. East Asian regionalism has made a big stride in the monetary field, in which a web of bilateral currency swap arrangements is in place. East Asia is also witnessing an outpouring of proposals for preferential trading arrangements at regional, sub-regional, and bilateral levels.

The prospect for an East Asian community or an East Asian Free Trade Area (EAFTA), the professed goal of the ATP process, is not promising since so many actors at different levels of political and economic development are involved. Similarly, sub-regional groupings like the one among China, Japan, and South Korea (Northeast Asian Free Trade Area or NEAFTA) have difficulties in making headway. By contrast, bilateral FTAs hold great promise since they involve only two like-minded actors. It is also possible for the participants to custom design FTA agreements according to their economic and political needs. Therefore, most of the East Asian countries are actively seeking FTAs with their major trading partners.

The rise of regionalism, as well as the spread of bilateral FTAs in East Asia, poses tough challenges to South Korea. The South Korean government is now faced with many alternatives for regional integration, ranging from bilateral FTAs to sub-regional groupings like NEAFTA, or region-wide economic integration like EAFTA, or trans-regional integration like APEC. Given its limited diplomatic resources, the South Korean government has to give a priority order to these options. Concerning bilateral FTAs, South Korea should carefully choose partners in order to maximize nets gains. Bilateral FTAs are by nature more or less discriminatory, and South Korea will lose greatly if it falls behind in the race for FTAs. However, the South Korean government faces a widespread opposition domestically against FTAs. South Korea needs to carve out a rational FTA strategy on the basis of close evaluation of potential partners not just to overcome domestic opposition but also to maximize the net gains from bilateral FTAs.

This paper intends to examine the current state of East Asian regionalism, figure out the challenges it poses to South Korea, and design South Korea's strategy toward East 
Asian integration in general and bilateral FTAs in particular. The rest of the paper is organized in the following way. The second section examines the rise of regionalism in East Asia since the economic crisis of 1997-8 and evaluates its future prospect. The focus is on exploring the implications of the growing interests in bilateral FTAs for the development of East Asian regionalism. The third section seeks to design a road map for South Korea to approach bilateral FTAs with major trading partners. It introduces an analytical model to evaluate the pros and cons of FTAs with potential partners. Concluding remarks follow in the fourth section.

\section{Current State of East Asian Regionalism}

\section{The Rise of East Asian Regionalism}

East Asia had for long remained under-identified and under-institutionalized as a region in spite of the high level of intra-regional economic interactions. 1) The financial crisis of 1997 was a watershed in the history of East Asian regionalism. Mahathir's long-dormant EAEC proposal had finally come to life in the aftermath of the crisis. The first annual APT heads of state summit was held in Manila in November 1999. At present, numerous regional cooperation initiatives are on the table. The enthusiasm for bilateral FTAs is sweeping through the East Asian region.

Since that crisis, there have been heated debates about the limitations of an East Asian development model based on individual states' capacity to exploit the open international trading system through state-led mobilization of national resources. ${ }^{2}$ ) Regionalism or regional free trade has been seriously discussed as an alternative in East Asia, not only to prevent the recurrence of financial crises but also to regain the momentum for economic development. The economic crisis also created a functional demand to manage monetary matters jointly. Consequently, regional cooperation is most advanced on monetary issues. The crisis also drove East Asian countries to pool their political power against international financial institutions like the IMF and the United States. The IMF and the United States dictated much of the East Asian response to the crisis, and the 'Washington consensus' was imposed upon the crisis-stricken countries as a condition for help. The widespread view that the IMF programs deteriorated the situation made the East Asians even more

1) Young Jong Choi and James A. Caporaso, "Comparative Regional Integration," in Walter Carlsnaes, Thomas Risse, and Beth Simmons, eds., Handbook of International Relations (California: Sage Publications, 2002), pp. 492-4.

2) T.J. Pempel, ed., The Politics of the Asian Economic Crisis (Cornell University Press, 1999). 
resentful, thereby driving them further in the direction of regionalism. ${ }^{3}$ )

In addition, the crisis fostered a sense of common identity, particularly the image of a region in adversity besieged by outsiders 'ganging up' in their attempts to exploit the difficulties that East Asian governments faced.4) This sense of common destiny must have pushed them to act together and facilitated the process of institutionalization in East Asia. For the first time in history, Japan and China worked together to come up with a financial arrangement to prevent the recurrence of financial crisis, and both of them became active participants in the talks to build regional institutions for economic cooperation.

\section{Prospect of East Asian Community}

Currently, the APT process is at the center of East Asian regionalism. As a direct descendant of Mahathir's EAEG/EAEC proposal, it is the most elaborate form of regional integration initiative in terms of regional boundary, identity, and institutions. Informal APT summit meetings began in 1997 in the aftermath of the East Asian economic crisis, and they became an official gathering in 1999. At the first annual APT summit held in Manila in November 1999, the participating leaders agreed to strengthen cooperation with a view to advancing East Asian cooperation in priority areas of shared interest and concern even as they look to future challenges. Its ultimate goal is to form an East Asian Free Trade Area by 2020 .

The level of institutionalization is low in the APT process. It has no independent secretariat. It remains basically a consultative forum of thirteen member governments, and bureaucrats have frequent meetings at various levels to discuss various issues of concern. Its future blueprint is well elaborated in the works of the two commissioned groups, i.e., the East Asian Vision Group (EAVG) and, its successor, the East Asian Study Group (EASG). $\left.{ }^{5}\right)$

In its annual summit meeting in November 2001, the APT member countries agreed

3) Paul Bowles, "Asia's Post-Crisis Regionalism: Bringing the State Back in, Keeping the (United) States Out," Review of International Political Economy, 9:2 (May 2002); Richard Higgott, "The Asian Economic Crisis: A Study in the Politics of Resentment," New Political Economy, $4: 1(1998)$.

4) John Ravenhill, "A three bloc world? The new East Asian regionalism," International Relations of the Asia-Pacific, Vol. 2 (2002), p. 175.

5) The EAVG was created in 1998 by the leaders of the ATP in response to the suggestion of South Korean President Kim Dae-jung. Its task was to study the ultimate objectives and the ways to effectively achieve them. The vision group was made up of two academics from thirteen member countries. After a three-year study, they submitted an ambitious plan for a regional bloc in November 2001. The EASG, composed of senior officials from the member states, was set up in 2001 to assess the recommendations of the EAVG. 
to launch an East Asian Summit (EAS) in the foreseeable future, as well as to scrutinize a plan for East Asian Free Trade Area on the basis of the EAVG report. Then, an East Asian community, though poorly defined, appeared in sight in light of the great enthusiasm and strong rhetoric exuded by participating leaders. When the EAVG handed in its final report to the 2002 APT summit, most of the key proposals contained in the EAVG report were either watered down or relegated to long-term goals. The EASG final report did not receive much media attention due to the high publicity of the China-ASEAN framework agreement on bilateral FTA. Major actors of the APT, particularly Japan, were more interested in assessing the repercussions of the possible China-ASEAN economic alliance and figuring out countermeasures against it.

These two reports are highly optimistic about the possibility of an East Asian community. East Asian cooperation, according to the EASG report, is both inevitable and desirable, and that such integration in East Asia will evolve over time.6) The reality, however, does not justify this optimism. There is a serious leadership problem in East Asia. Right now, neither China nor Japan is willing to play a leadership role. A kind of dual power structure emerged concerning East Asian regionalism. More specifically, secondary powers like ASEAN and South Korea are leading the APT process whereas major powers like China and Japan are in the backseat.

The United States is not an enthusiastic supporter of East Asian regionalism, either. The US government is casting a suspicious eye on the APT process, and it is certain that the United States will act resolutely to abort any East Asian initiative that may seriously undermine its strategic and economic interests. Therefore, Japan and South Korea, two major allies of the United States in East Asia, cannot be overly enthusiastic. about the emergence of a strong East Asian identity or an East Asian community. Moreover, the United States still accounts for the lion's share of trade flows, investment flows, bank transfers, telephone calls and travel of nearly all East Asian countries.

Trans-national societies and trans-national institutions, the prime movers of regional integration according to neofunctionalism, are underdeveloped in East Asia. A neoliberal consensus, which has propelled regional integration in other regions, is still weak. Domestic political conditions are not favorable, either. Democratization, liberalization, and power shift from protectionist to pro-liberalization forces are generally in short supply. Although East Asia has a stronger common identity now than a decade ago, question still remains regarding the extent of newly forged collective identity as well as the magnitude of its positive impact on regional integration. The divergence of historical experiences,

6) The East Asian Study Group, The Final Report of the East Asian Study Group, (November 2, 2002), p. 5. 
cultural and linguistic diversity, and differing political ideologies still pose formidable barriers to regional cooperation. All these factors indicate that an East Asian economic community is in the distance.

While the initiatives to build an East Asian community are stagnating, regional monetary cooperation is proceeding rapidly.7) Since financial problems lay at the heart of the economic crisis of 1997 , it is not surprising that regional cooperation has proceeded more rapidly on monetary issues than on trade. Moreover, monetary cooperation, unlike most of trade deals, does not create powerful domestic losers. ${ }^{8)}$ This is why Japan, a hegemonic defector from regional cooperation, has played a leadership role in monetary cooperation.

In the aftermath of the regional financial crisis, Japan proposed an Asian Monetary Fund in September 1997. Although the proposal was rejected immediately by the United States on the ground that it might undermine the IMF, it was just the beginning. The Japanese government not only provided liquidity to the crisis-hit economies through the Mayazawa Plan but also proposed the Chiang Mai Initiative in May 2000, which was basically an effort to set up a region-wide currency swap arrangement to prevent currency crises and the escalation of such crises in the case of recurrence in the future.

The current talks of regional currency swap arrangements have so far created a series of bilateral swap arrangements between East Asian countries. East Asia has yet to see a genuine regional institution on monetary issues. ${ }^{9)}$ As the European experience shows, monetary integration poses more threats to national sovereignty and is therefore more difficult than market integration. Monetary integration, however, has much less spillover effects on societal integration than market integration. Consequently, monetary and financial cooperation so far made in East Asia, notwithstanding its symbolic values, will have limited impact on the actual progress of regional integration.

\section{Bilateral FTAs and East Asian Regionalism}

East Asian regionalism had long been represented by both trans-Pacific cooperation and sub-regional cooperation in Southeast Asia. The former, the Asia-Pacific cooperation

7) Dieter and Higgott define ASEAN+3 process as monetary regionalism different from traditional trade-led regionalism. Heribert Dieter and Richard Higgott, "Exploring Alternative Theories of Economic Regionalism: From Trade To Finance in Asian Co-Operation?" Review of International Political Economy, 10:3 (August 2003), p. 430.

8) Eric Helleiner, State and The Emergence of Global Finance: From Bretton Woods to the 1990s (Ithaca: Cornell University Press, 1994), pp. 203-5.

9) John Ravenhill (2002), p. 187. 
endeavors that can be traced back to the pre-World War period, had been unproductive until 1989 when APEC, the first-ever intergovernmental institution in the Asia-Pacific region, was formed. It has yet to make a quantum leap to accomplish its professed goal of regional free trade. The latter, represented by ASEAN, could exert only a limited impact on the growth of East Asian regionalism partly due to the lack of internal cohesion and partly to due its limited economic power. The common problem to these two initiatives was that too many, too different actors were involved.

[ Table 1] Free Trade Agreements (FTAs) by East Asian Countries

\begin{tabular}{|c|c|c|}
\hline Intra-Regional FTAs & Status & $\begin{array}{l}\text { Year (Proposed } \\
\text { or Implemented) }\end{array}$ \\
\hline Singapore-Japan & Implemented & 2002 \\
\hline Korea-Japan & Under Negotiation & 1998 \\
\hline Korea-Singapore & Signed & 2004 \\
\hline Korea-Thailand & Joint Study & 2001 \\
\hline Japan-Thailand & Discussion & 2002 \\
\hline AFTA(ASEAN Free Trade Area) & Implemented & 1992 \\
\hline China-Japan-Korea & Joint Study & 2001 \\
\hline ASEAN-Japan & Joint Study & 2002 \\
\hline EAFTA $($ ASEAN+3) & Discussion & 2000 \\
\hline ASEAN-Korea & Discussion & 2002 \\
\hline \multicolumn{3}{|l|}{ Inter-Regional FTAs } \\
\hline Singapore-New Zealand & Implemented & 2001 \\
\hline Singapore-EFTA & Implemented & 2003 \\
\hline Korea-Chile & Signed & 2002 \\
\hline Singapore-US & Signed & 2003 \\
\hline Singapore-Mexico & Under Negotiation & 1999 \\
\hline Singapore-Australia & Under Negotiation & 2000 \\
\hline Singapore-Chile & Under Negotiation & 2000 \\
\hline Singapore-Canada & Under Negotiation & 2001 \\
\hline Japan-Mexico & Under Negotiation & 1999 \\
\hline Korea-New Zealand & Joint Study & 2000 \\
\hline Japan-Chile & Joint Study & 2000 \\
\hline Korea-Mexico & Discussion & 2000 \\
\hline Korea-Australia & Discussion & 2000 \\
\hline Korea-United States & Discussion & 2001 \\
\hline Japan-Canada & Discussion & 2000 \\
\hline ASEAN-CER(Australia+New Zealand) & Under Negotiation & 1999 \\
\hline
\end{tabular}

The region had not known bilateral FTA until recently, which is basically a deal between the two like-minded countries. Bilateral FTAs are not just more feasible than any 
other forms of regional integration; they may also trigger a domino effect throughout East Asia. ${ }^{10)}$ The evolution of the EU from a five-member grouping into a twenty five-member entity and the development of North American integration from a bilateral FTA between the United States and Canada support this reasoning. In this sense, the rise of interests in bilateral FTAs in East Asia may facilitate the emergence of an East Asian community. 11)

As indicated in Table 1, East Asia is witnessing a rapid growth of FTAs proposals. So far, only a few of them have come to fruition. Singapore is leading the way to become a hub of regional FTAs while major countries in Northeast Asia (e.g., China, Japan, and South Korea) are cautiously following its footsteps. The Japan-Singapore Economic Partnership Agreement (JSEPA) signed in January 2002 was the first ever between East Asian countries. JSEPA exposed a degree of domino effect by setting off a series of FTA proposals between East Asian countries.

China, casting a weary eye on the possibility of Japan's enhanced position in Southeast Asia, proposed a China-ASEAN FTA in November 2000. In November 2001, both sides officially agreed on a timetable to achieve a free-trade area within 10 years. Japan answered by unveiling a new initiative to deepen economic ties with ASEAN in January 2002, including pacts on investment, services, education, tourism, and science and technology, when Prime Minister Koizumi made a tour of five major ASEAN countries. ${ }^{12}$ ) Then came the joint announcement of China and ASEAN at the APT summit in November 2002 to go ahead with a bilateral FTA. The Japanese government responded with its own proposal for an FTA with ASEAN. It was, however, overshadowed by a more ambitious call by China for a Northeast Asian FTA (NEAFTA) encompassing China, South Korea and Japan. South Korea also jumped on the FTA bandwagon, by becoming a party of about six FTA proposals in East Asia. Just like the falling dominos, the quest for bilateral FTAs is spreading across East Asia.

The current drive for FTAs may lead East Asia into two different directions. One is the gradual formation of a free trade area among market economies genuinely dedicated to economic liberalization and integration. The other is the emergence of a group of contending coalitions of economies more interested in enhancing their political leverages against each other or against non-members outside the region. The former is not picking

10) Richard E. Baldwin, "A Domino Theory of Regionalism," in Richard E. Baldwin, Pertti Haaparanta, and Jaakko Kiander, eds., Expanding Membership of the European Union (Cambridge: Cambridge University Press, 1995).

11) Young Jong Choi and Nae Young Lee, "A Comparative Study of Regionalism in East Asia and the Americas," Asian Perspective, 26:3 (2002), p. 189.

12) Takehiko Kajita, "Japan's New ASEAN Policy Comes as China Rises," The Japan Times, January $15,2002$. 
up momentum at this point, as its potential nucleus the Japan-Singapore EPA shows no sign of expansion. In fact, it is highly questionable if East Asian economies, with the exception of Singapore, are either ready for or sincerely interested in region-wide free trade. The latter is more likely to happen judging from the intensifying rivalry between Japan and China to take the leadership position in East Asia.

China's interest in FTAs is largely driven by political motivations. East Asian regionalism or an FTA with ASEAN can tame the fear of 'China threat' among East Asian countries, particularly ASEAN members, serve its foreign policy goal of anti-hegemonism, and undermine Japan's dominant position in (South) East Asia. It is not clear if China is ready for a more dose of liberalization on top of the requirements imposed by the WTO. It is also hardly convincing that ASEAN is serious about free trade. ASEAN has experienced more than enough difficulties in achieving internal free trade (i.e., AFTA). A bilateral FTA with China will add far more challenges and difficulties to the already troubled ASEAN economies. In this sense, the proposed China-ASEAN FTA is a political maneuver, and will only intensify competition for political influence among major actors in the region, particularly between China and Japan. The China-ASEAN economic alliance in the form of bilateral FTA is more likely to turn into an anti-Western pressure group than a catalyst for a genuine regional free trade.

South Korea's choice, whether to side with China or Japan or both, is critical for the future of East Asia. A Japan-South Korea FTA, which would bring together the two biggest democratic, capitalist economies in East Asia, can become an effective balancer against the emerging China-ASEAN economic alliance. This may facilitate the formation of a zone of peace among developed capitalist countries in East Asia by adding Singapore and other qualified countries in the future. This grouping, if kept low profile politically and open to outside, may gradually expand to cover the whole region just like the widening of EU to other parts of Europe. However, South Korea cannot treat China lightly in view of its huge domestic markets, strong growth potential, and fast-growing political weight. The next section will specifically deal with South Korea's strategy toward FTA, particularly concerning the choice of FTA partners.

\section{South Korea's FTA Strategy}

\section{Introduction}

In purely economic terms, countries cannot lose by liberalizing their economies. 
Therefore, the more is the better as long as FTAs are not incompatible with each other. FTAs may, however, add regulatory complexity and confusion to trade policy, especially in the administration of overlapping, contradictory and complicated rules of origin requirements. In this sense, unilateral liberalization is a better option in terms of transaction costs, and the resources spent in negotiating and administering FTAs can be better used. Given the limited diplomatic resources and staunch domestic opposition to economic liberalization, the South Korean government should carefully pick FTA partners and maximize net political and economic gains from the agreements.

FTAs provide various economic and political benefits. Economically, members can reap efficiency gains and trade gains. The former comes from increased competition and scale of economies that arise as separate national markets become more integrated. The latter crops up as trade barriers are removed and the direction of trade changes as a result. If imports from FTA partners substitute domestic production, we call it trade creation; and if they substitute imports from the rest of the world, we call it trade diversion. Besides trade, the location of economic activity will also change according to comparative advantage within the integrating countries. In order to maximize economic benefits from FTA, removing border barriers are insufficient. It further requires genuine efforts to harmonize different regulatory systems (the so-called deep integration).

FTA can be pursued for political purposes, e.g., to increase political weight for international bargaining, to promote peace and security between members, to lock in domestic reforms, and to satisfy the interests of strong domestic interest groups. FTAs also involve political costs even though countries cannot lose by opening up their economies. They will include the loss of national autonomy, the costs incurred in negotiating and implementing the agreement, and the painful restructuring inevitably accompanied by the increased competition.

The expected benefits and costs of FTAs are largely determined by the attributes of partners, the depth and width of economic integration, the enforceability of FTA rules, and the policy to outside (open or closed). As we will see, with whom is particularly important since the rest are closely associated with it. In order to maximize the net gains from FTA, countries need to carefully select FTA partners. For this purpose, policy-makers need a tool to evaluate FTA partners, to see what are their pros and cons, and to identify problems and if possible to come up with solutions.

Most studies on FTAs (or FTA partners) done by economists have largely focused on their impacts on trade balance between participating countries. The outcomes have quite often been arbitrary and inconclusive since the amount and direction of trade is determined by so many factors, political and economic, domestic and external, and short-term and 
long-term. ${ }^{13)}$ Moreover, since FTA is the mildest form of economic bloc, it cannot be so discriminatory as to provide exclusive benefits for participants. The rule of origin, which is designed to enable FTA to work as an economic bloc, can also be very costly and burdensome. Many countries or economic blocs are members of more than one FTA. For all these reasons, participants to FTA are more interested in minimizing political costs than maximizing economic gains. This explains why FTA negotiations take so long and why the texts of the agreements are in general very long and complicated, sometimes reaching more than two hundreds pages in length like the NAFTA.

Since FTAs are in general between two countries, political gains such as enhanced bargaining power and security are likely to be limited. More significant gains will accrue from the improvement of efficiency (as a result of increased competition and economies of scale), as well as from domestic reforms (e.g., liberalization, restructuring, deregulation, flexibility in the labor market, adoption of global and regional standards, fiscal soundness, etc). Without these liberalizing reforms, many studies show that even the economic integration with an ideal partner cannot guarantee economic improvement.14) For these reasons, we need to put more emphasis on the self-reforming effects of FTA than on the short-term effects on the balance of trade.

We may conclude in advance that wider and deeper integration is more desirable; domestic reform and the credibility of reform policies deserve serious consideration in choosing FTA partners; and a proper enforcement mechanism is necessary for countries like South Korea that have only a limited political leverage against potential FTA partners. Key issues concerning bilateral FTAs are what the chance of striking a successful agreement is, how desirable the outcomes of FTA negotiations will be, and whether a proper implementation can be secured.

\section{Analytical Framework}

Researches on FTA usually suggest a number of factors that need to be taken into account in selecting partners such as trade and investment opportunities, level of trade barriers, feasibility, political effects, domestic reform effects, etc.15) This study will lump

13) For example, the researches on the impact of Japan-Korea FTA on trade balance of the two countries present widely different outcomes. See Inkyo Chung, "Korea's FTA Policy: Focusing on Bilateral FTAs with Chile and Japan," Discussion Paper 02-02 (Seoul: Korean Institute for International Economic Policy, 2002), p. 45.

14) This convergence did not take place in Greece, although it joined the EU earlier than Portugal and Spain, because Greece did not implement the necessary reforms after joining the EU. World Bank, Trade Blocs (New York: Oxford Press, 2000), p. 51.

15) Maurice Schiff and L. Alan Winters, Regional Integration and Development (Washington DC: 
them together into two key variables: level of development (or income-level) and relative power.

\section{1) Level of Development}

Level of development comes first in many studies on economic integration. This factor is related not just to trade and investment opportunities but also to learning and reform effects of FTA. Although the level of development is a comprehensive concept encompassing economic, political and legal aspects of life, it can be conveniently measured by income level.

The history of economic integration shows that income level has been the decisive factor to the success of FTA deals. For example, most FTA agreements involving high-income countries (namely North-North or N-N integration and in recent years North-South or N-S integration) have survived, successfully locking in their liberalizing policies. The record among developing countries (namely South-South or S-S integration) is not impressive. Most of the S-S integration agreements have either collapsed or never taken off.16) This trend suggests that South Korea as a middle-income country is better to choose high-income countries for successful FTAs.

Income level is also closely related to the distribution of income. The World Bank Report of 2000 on regional trading blocs shows that comparative advantage produces convergence in North-North blocs, but divergence in South-South blocs. ${ }^{17)}$ The strong performance of Ireland, Portugal, and Spain, who have made substantial progress in closing the gap with richer members after joining EU, is a good example of the convergence effect. In this case, labor-intensive production activities moved toward lower-wage countries, thereby raising income levels there. Learning effect also plays a significant role in the process of convergence, particularly when the high-income country is a key producer of knowledge. By contrast, in the Central American Common Market (CACM) and the Economic Community of West African States (ECOWAS), there are symptoms of divergence, that is to say, the richer Southern countries have substantially gained market share at the expense of the poorer. S-S blocs typically discriminate against the North, and by so doing help those countries within the bloc that are the closest competitors with the North, namely the highest-income countries in the bloc. ${ }^{18)}$

Income level also affects the depth and width of economic integration. $\mathrm{N}-\mathrm{N}$ integration

World Bank, 2003), pp. 64-74.

16) World Bank (2000), p. 25.

17) World Bank (2000), pp. 127-8

18) World Bank (2000), pp. 25-6. 
features increasingly deeper and wider integration. FTA between high-income countries are likely to involve harmonization of regulatory systems beyond removing border barriers, and it is a commonplace for $\mathrm{N}-\mathrm{N}$ integration to cover a wide range of issues from trade, investment, labor, and environment. N-S integration is also heading in the same direction. These new trends are leveled at maximizing the benefits of market integration. However, it involves greater loss of sovereignty and policy autonomy, greater political commitment, and more demanding domestic reforms at the same time.

\section{2) Relative Power}

Economic integration is basically a political action. It serves various domestic and external political purposes. Domestically, it satisfies the interests of influential groups. Externally, it may be conducive to forming a strategic partnership for peace and security, as well as to enhance the bargaining power of participating countries. As in other political bargaining, power matters in agenda setting, bargaining, and implementation of FTA agreements. As is well known, power is a multi-dimensional concept encompassing political, military, and economic components. In a highly interdependent world where military option is extremely costly, power comes mainly from economic strength and the nature of economic relations. If power is understood as the 'economic ability to reward and punish,' it is close to Albert Hirschman's influence effect of foreign trade, in which trade dependence becomes the root cause of power with the interruption of trade relation s. ${ }^{19)}$ Similarly, Keohane and Nye argue that the asymmetry in economic interdependence (namely difference in sensitivity and vulnerability) creates a point of leverage for less dependent states, which can be applied to impose demands on more dependent states. ${ }^{20}$ ) In this case, trade dependence and domestic market size are useful indicators of power. If power is understood as the capability to finance and support diplomatic endeavors, it can be measured by the size of GDP.

Granting that power is an important variable, it does not necessarily follow that a country will gain more by choosing weaker partners. FTAs can be pursued as a means of enhancing bargaining power or cementing strategic partnership. For this purpose, powerful partners have more to offer. Moreover, as hegemonic stability theory suggests, powerful countries may provide the leadership necessary for economic integration. It is therefore not a mere coincidence that EU and the United States are at the center of the

19) Albert O. Hirschman, National Power and the Structure of Foreign Trade (Berkeley: University of California Press, 1980), p. 16.

20) Robert $\mathrm{O}$. Keohane and Joseph Nye, Power and Interdependence (Harper Collins Publishers, 1989), p. 11-19. 
most of successful FTAs.

FTA can also be pursued as a means of locking in liberalizing reforms. This lock-in effect will be strong if the partner has the power and willingness to enforce these reforms. For this purpose, powerful partners with a strong commitment to liberalizing reforms are desirable. There are many instances of N-S integration designed specifically to lock in to economic and political reforms of the South. For example, NAFTA was clearly about trade. However, both the Mexican and US governments had the intention to lock in the broad range of economic reforms that the Mexican government had undertaken in the preceding years. ${ }^{21)}$ In this sense, N-S FTA will reduce the likelihood of a Southern country to renege on its trade liberalization and enhance the credibility of its reform policies.

Just as international agreements are useful as a means of constraining (or self-restraining) the behavior of the weaker side, they can also be used to constrain the stronger side, particularly its arbitrary exercise of power. In this sense, legalized institutions are like a double-edged sword, binding both the powerful and the weak. In spite of the expansion of legalization in contemporary world politics, however, it is still problematic to secure the commitment of the powerful to international agreements. ${ }^{22)}$ This problem can be mitigated if there are domestic constituencies that support international agreements and/or the rule of law is firmly rooted in the powerful countries so that foreign actors may have an equal access to the law.23) Most of the advanced, democratic countries can largely meet these conditions. In this sense, the US, EU, and Japan are different from developing powers like China, India, and Brazil, where state is stronger than society and the rule of law tradition is tenuous.

\section{3) Analytical Framework}

As stated above, the income level and relative power of FTA partners are the two key variables that determine the nature of economic integration. From the perspective of middle-income countries like South Korea, we can construct a two by two matrix like Figure 1. For reasons of simplicity, two key variables are presented in dichotomy, high or low and strong or weak.

21) Schiff and Winters (2003), pp. 109-110.

22) Judith Goldstein, Miles Kahler, Reober O. Keohane, and Anne-Marie Slaughter, "Introduction: Legalization and World Politics," International Organization, 54:3 (Summer 2000), pp. 391-3.

23) Lisa L. Martin and Beth A. Simmons, "Theories and Empirical Studies of International Institutions," in Peter J. Katzenstein, Robert O. Keohane, and Stepan D. Krasner, eds., Exploration and Contestation in the Study of World Politics (Cambridge: The MIT Press, 1999), pp. 107-9. 
[Figure 1] FTA Partners: Power, Income Level, and Likely Shapes of Economic Integration

\begin{tabular}{|c|c|c|c|}
\hline & \multicolumn{2}{|c|}{ Relative Power } \\
\hline & & Strong & Weak \\
\hline \multirow{2}{*}{$\begin{array}{r}\text { Level of } \\
\text { development }\end{array}$} & High & $\begin{array}{l}\quad \text { I } \\
\text { (1) convergence effect } \\
\text { (2) largest (from trade and } \\
\text { efficiency effects) } \\
\text { (3) largest } \\
\text { (4) deeper and wider } \\
\text { (5) highly effective } \\
\text { (6) large political costs (loss of } \\
\text { autonomy and domestic } \\
\text { restructuring) } \\
\text { (7) US, EU, Japan }\end{array}$ & $\begin{array}{l}\text { II } \\
\text { (1) convergence effect } \\
\text { (2) substantial (from trade and } \\
\text { efficiency effects) } \\
\text { (3) moderate } \\
\text { (4) deep and wide } \\
\text { (5) effective } \\
\text { (6) some political costs (but easy } \\
\text { to exit) } \\
\text { (7) Singapore, Australia, New } \\
\text { Zealand }\end{array}$ \\
\hline & Low & $\begin{array}{l}\text { III } \\
\text { (1) leveling effect } \\
\text { (2) substantial economic gains } \\
\text { (largely from trade effect) } \\
\text { (3) little } \\
\text { (4) limited to trade liberalization } \\
\text { (5) highly vulnerable to } \\
\text { opportunistic behavior } \\
\text { (6) large domestic costs (domestic } \\
\text { restructuring) } \\
\text { (7) China, ASEAN, India }\end{array}$ & $\begin{array}{l}\quad \text { IV } \\
\text { (1) divergence effect } \\
\text { (2) some } \\
\text { (3) little } \\
\text { (4) limited liberalization in trade } \\
\text { (5) not so problematic } \\
\text { (6) small domestic costs } \\
\text { (7) less-developed ASEAN } \\
\text { countries, North Korea, } \\
\text { Mongolia }\end{array}$ \\
\hline
\end{tabular}

Note: Numbers in parentheses stand for the following: (1) income effect; (2) economic gains; (3) reform effect; (4) scope of integration; (5) enforcement; (6) domestic costs; (7) example

In quadrant 1 of Figure I, FTA partners are advanced, high-income countries with a substantial political leverage over South Korea. In this quadrant, we expect that great economic benefits will accrue from various sources like efficiency, trade, learning, as well as domestic reform effects. Convergence effect is expected on national income, and a degree of leveling effect on social standards is also inevitable for high-income partners. In order to mitigate the adverse effects on their national incomes and other social standards, they will try to exercise political leverage to draw asymmetric agreements, in which the benefits to the developing partner are either reduced or appropriated by them through side conditions on the environment, labor regulations, rules of origin, and the like.

FTAs are likely to include not just trade liberalization but also deep integration in other areas like economic policy coordination and regulatory harmonization. In view of the power gap, liberalizing reforms in South Korea will be very hard to reverse, and FTA agreements are likely to be enforced effectively. However, this type of FTA is not without costs. Particularly, the loss of national autonomy is inevitable, and the tough domestic restructuring required will present formidable political barriers. Still, the recent experience 
of economic integration in Europe and North America indicates that this type of FTA has a good chance to succeed. The most critical issue for South Korea is how to overcome domestic opposition against the loss of national autonomy. The United States, Japan, and EU may belong here.

Quadrant 2 represents FTA partners with a high income level but far less leverage than quadrant 1 . They have small domestic markets and tend to maintain symmetric economic interdependence. Judging from their income level, a degree of convergence effect is expected. Considering the limited market size, however, economic benefits from FTAs are likely to be smaller than quadrant 1 . The extent of domestic reforms required by these partners, given their limited bargaining leverage, will be far less than the case of quadrant 1. Similarly, the possibility and severity of punishment in case of defection from the agreement will not be so imposing as to lock in domestic reforms. The overall shape of economic integration in quadrant 2 will be shallower and narrower than quadrant 1. However, domestic political costs are expected to be smaller than quadrant 1 since the exit from the deal is relatively easy. A FTA with this type of partner will face less domestic opposition and therefore have a pretty good chance to succeed. Examples may include Singapore, Australia and New Zealand.

Quadrant 3 features powerful, developing countries as FTA partners. Obviously, their large domestic markets are attractive. However, because of their low income-level, a degree of leveling effect on domestic standards of South Korea is inevitable. A race to the bottom in social standards, the exodus of labor-intensive industries, and the grueling domestic restructuring may also be feared. In order to handle these adverse effects, substantial political leverage will be necessary against these low-income partners. The problem is that quadrant 3 has more leverage than South Korea. This presents daunting challenges for striking a mutually acceptable FTA deal. Even if the deal gets through, more serious trouble is expected at the implementation stage. There is no effective means to prevent the opportunistic behavior of this type of partner. Under the circumstances, deep integration is not feasible. FTA will largely be limited to reducing border barriers, and there will be little domestic reform effect on the high-income partner. An FTA with this type of partner is not expected to sail through. China, ASEAN, and India may belong to this category.

Quadrant 4 represents small, low-income economies as FTA partners. Judging from their income level and market size, economic gains from FTA are expected to be relatively small. Political gains and domestic reform effects will also score low. It is not easy for developing countries to achieve a critical mass of political influence in the global trade negotiations through economic integration. Theoretically, middle-income countries like 
South Korea can become the beneficiaries of the backwash effect, in which production activities tend to be concentrated in the highest income country.24) In reality, it is not easy for a middle-income country to form a discriminatory economic bloc with a group of low-income countries. Furthermore, the divergence effect can create tensions between FTA members that may lead to the failure of the agreement. In general, FTAs with this type of partner cannot make much difference for South Korea, both economically and politically. In East Asia, less-developed ASEAN countries, North Korea, and Mongolia may be included in quadrant 4 .

\section{Policy Implications for South Korea}

\section{1) Policy Priority}

As seen above, FTA is the lowest stage of economic integration, largely between two countries. As a result, political and economic gains are expected to be far smaller than higher forms of integration with a large membership. Political benefits will lie more in improving participant's image and credibility as a free trader than in increasing political weight against non-members. Similarly, economic benefits will accrue mostly from increased competition and efficiency gains rather than from discrimination against non-members. In this sense, a significant part of the gains from FTAs are intangible. Therefore, the simple calculation of tangible benefits like the effect on trade balance is prone to lead us to partial, unconvincing conclusions.

If intangible aspects like domestic reform and credibility gain are added to the equation, the rank order of potential gains among the four types of FTA partners will be like the following: quadrant $1>$ quadrant $2>$ quadrant $3>$ quadrant 4 . South Korea is known for high domestic rigidity and is suffering from low credibility in the international economic circle to its economic policies. FTAs with the quadrant 1 type of partners like Japan and the United States will contribute greatly to Korea's enhancing domestic flexibility and international reputation. The issue is how to manage huge political costs that may emanate from the loss of national sovereignty, inevitably asymmetric nature of the agreement, and the harsh domestic restructuring required by the deal. An FTA with the quadrant 2 type like Singapore will involve far less political costs but much less overall political and economic gains than quadrant 1 . Therefore, it will have easier time to come to a successful conclusion. Quadrant 3 offers great potential gains with large domestic markets. This asset, however, can turn into a political liability for South Korea. For

24) Roger D. Hansen, "Regional Integration: Reflections on a Decade of Theoretical Efforts," International Organization, 21:2 (1969), p. 255-6. 
example, China is a promising FTA partner, but it will be hard to put a strong China under control. The powerful, increasingly unruly China can be better managed through multilateral institutions or joint efforts with the regional powers like Japan and the US than a bilateral pact. This requires a cautious approach to an FTA with China. As to less-developed East Asian countries that belong to quadrant 4, we may safely assume that FTAs will have no significant ramifications for South Korea politically and economically. This assessment does not rule out the benefits of close economic relations with them.

\section{2) South Korea-Japan FTA}

The above analysis leads South Korea to focus on Japan, EU, and the United States for FTA. Currently, while both the US and EU show no strong interest, Japan is serious about a deal with South Korea. In view of the historical antagonism and the negative repercussions on domestic politics, the negotiation is not going to sail through. However, instead of succumbing to domestic opposition, both sides need to push various deep integration measures, e.g., removal of non-tariff barriers, reforms on competition policy, investment protection, deregulation and macroeconomic policy coordination, etc. By so doing, South Korea and Japan can not only make their respective economies more open and efficient, but also build a nucleus for a free trade area in the whole East Asian region. Just like the expansion of Canada-US FTA into NAFTA, a Japan-South Korea FTA may easily develop into a trilateral FTA including Singapore. This grouping can gradually expand to cover the whole region. The United States, traditionally a spoiler to East Asian regionalism, will have no reason to fear about the one led by the practitioners of free trade like Japan and South Korea.

The biggest stumbling block to both Japan and South Korea is, however, their protectionist agriculture sector. As for Japan, its first success in the FTA business was made possible since Singapore had no meaningful agricultural sector; the Singaporean economy was highly advanced; and its income level was higher than that of Japan. Even with these favorable conditions for economic integration, the Japan-Singapore FTA deal could not sail through due to the opposition from the farm lobby. South Korea also had more than enough difficulties in concluding its first FTA with Chile in 2002. Therefore, its ratification cannot be taken for granted both in South Korea and Japan. Another problem is that this grouping may clash with China or a newly emerging China-ASEAN bloc. A South Korea-Japan FTA should remain open to other East Asian countries, particularly to those that are committed to economic liberalization and democratic values, not only to prevent unnecessary political confrontation between the two economic giants but also to facilitate a region-wide free trade area. 


\section{3) China}

Since the establishment of formal diplomatic relations between Korea and China in 1992, bilateral economic relations have experienced a rapid growth. In 2001, China became Korea's second-largest export destination, overtaking Japan; and China was the second-largest destination for Korea's foreign direct investment (FDI) outflows. In 2003, China overtook the United States as Korea's primary export destination, and China also became the primary destination for Korea's FDI outflows. In 2002, Korea achieved a record trade surplus with China of about $\$ 6.4$ billion and further up to $\$ 13.2$ billion in 2003. In 2003, the number of Korean FDI projects in China accounted for 59.7 percent of the total number of Korean foreign investments in the same period; and the amount of Korean FDI in China accounted for 37.1 percent of Korea's total FDI.25) China's rapidly growing economy increasingly overshadows the prominence of the U.S. market for the South Korean economy.

In consideration of the booming bilateral economic relations, as well as China's higher tariff rates than Korea's, many researchers and businesspersons in Korea are enthusiastic about an FTA with China. Taking a step further, the Korean government is envisioning a Northeast Asian economic bloc by establishing a China-Korea-Japan FTA, in which Korea would play the role of a regional hub. The South Korean government expects a bilateral or a regional FTA will create synergy between the two most dynamic economies of the world by combining South Korea's advanced management skills and technology with China's abundant labor, low manufacturing costs, and huge potential market.26) South Korea's political leadership has become more than willing to embrace China as an important regional partner. The South Korean public increasingly perceives the United States an obstacle to inter-Korean reconciliation and unification while China is viewed as supportive and helpful. Recent polls on the South Korean public unmistakably show that the United States is a more serious threat to Korean security than China.

South Korea's almost blind euphoria over the benefits of an FTA with China as well as over the prospect of China-Korea relations seems too nave, particularly if we consider China's increasing economic might and political clout. China's leverage arises from its huge domestic markets and South Korea's asymmetric dependence on Chinese markets. For example, while China accounted for $12.1 \%$ of Korea's exports in 2001, South Korea took only $4.7 \%$ of China's total exports. Bilateral trade balance also indicates more pain on the

25) Chang-kyu Lee, "Economic Relations between South Korea and China," World Economy (The Korea Economic Institute, Washington DC: 2004), pp. 69-70.

26) Seongho Sheen, "Tilting toward the Dragon: South Korea's China Debate," Special Assessment: Asia's China Debate (Asia-Pacific Center for Security Studies, December 2003), p.4 
Korean side in case of the disruption of bilateral economic relations. South Korea has witnessed China's leverage over itself in a series of bilateral trade conflicts, most blatantly during the garlic war of 2000.27) China is neither fully committed to international norms under the WTO nor has a predictable legal system. The Chinese government also enjoys a great leeway in using economic statecraft thanks to the underdevelopment of domestic society or its autonomy from domestic politics. Therefore, the trading world would better be prepared for a Chinese version of unilateralism, similar to that of the United States but far less committed to free trade.

At present, China is neither ready nor willing to strike a FTA with South Korea. As the case of China-ASEAN FTA shows, China's approach to FTA is largely driven by strategic and political concerns. Similarly, China's proposal for a trilateral FTA with South Korea and Japan was an attempt to counteract or prevent a potential Korea-Japan economic alliance through FTA. The Japanese government is well aware that China is neither ready nor willing to strike a FTA with it. China is at the very end of Japan's list of FTA candidates. ${ }^{28)}$ Even if China become serious about FTA beyond its rhetoric, South Korea will still face lots of difficulties in pulling out an agreement that may limit potential domestic disturbances to an acceptable level, as well as in securing proper implementation of it. China can best take advantage of its leverage in a bilateral setting. Therefore, South Korea would better go trilateral (including Japan) or regional or multilateral than bilateral not only to maximize the benefits of free trade but also to transform China into a reliable and respectful trade partner.

\section{4) Broader FTAs}

South Korea, as a trading state, has achieved rapid economic growth by effectively taking advantage of the open international trading system. Simultaneously, South Korea has kept strong reservations against economic liberalization and market-oriented reforms, to a degree unbecoming of its global economic status. Tough choices are ahead of this Janus-faced South Korea in times of globalization and regional economic integration.

27) It was a dispute over Chinese garlic, which had flooded the Korean market in 1999 with a ten-fold increase. In response, South Korea imposed $315 \%$ tariffs on garlic imports from China. China answered by banning imports of polyethylene and mobile phone equipment, two rapidly growing sectors for South Korean exporters to China. The South Korean government and the Korean polyethylene and mobile phone equipment companies had no choice but to succumbed to China's pressure tactics. Scott Snyder, The Insatiable Sino-Korean Economic Relationship: Too Much for Seoul to Swallow? Comparative Connection (CSIS Pacific Forum, 3rd quarter 2000).

28) MOFA, Japan's FTA Strategy (Summary, October 2002), http:/www.mofa.go.jp/policy/economy/ $\mathrm{fta} / \mathrm{strategy0210.html} \mathrm{(2004.} \mathrm{8.10).}$ 
South Korea has traditionally supported broader schemes of regional integration like East Asian community or Asia-Pacific community than narrow sub-regional groupings or bilateral FTAs. This may be a rational policy choice for a trading state in view of the logic of the scale of economy. That is to say, if free trade is beneficial, the greater economic gains will accrue from the larger free trade area. In terms of feasibility, however, the smaller grouping is superior to the larger one. It is rather puzzling why South Korea has ambitiously pursed a comprehensive FTA that has a far less chance to succeed.

A logical answer can be found in the political realm. The South Korean government, with a high degree of domestic rigidity and strong opposition to liberalization, has in a sense advocated a region-wide economic integration because it is beyond the reach in the near future. By so doing, South Korea can give an impression that it is serious about trade liberalization and regional cooperation to both domestic and international audiences. Furthermore, since Korea cannot compete well in the FTA race that is underway in East Asia due to domestic opposition, a region-wide FTA can become a useful counter move to slow down this race. A larger grouping is also expected to dilute the influence of major regional powers like Japan, China, and even the United States.

South Korea, if it is really interested in region-wide free trade, should start from a bilateral FTA, particularly with quadrant 1 type of country like Japan. Even when shooting for a FTA in East Asia, however, South Korea cannot or should not overly enthusiastic about an exclusively East Asian regional bloc, particularly the one dominated by potentially anti-Western, developing economies. Joining this kind of grouping may jeopardize South Korea's relationship with the United States. The recent emphasis on Northeast Asia or East Asia by the Korean leadership is in part driven by the prospect of balancing or replacing US influence in the region. South Korea's ultimate goal as a trading state has to be free trade in East Asia, Asia Pacific and the world. For this purpose, FTAs with other blocs like EU, MERCOSUR, and NAFTA will be useful.

\section{Conclusion}

This paper is an attempt to assess the current state of East Asian regionalism and draw South Korea's strategy toward East Asian regional integration in general and bilateral FTAs in particular. East Asian regionalism has been taking on a more concrete shape in recent years, particularly after the financial crisis of 1997-8. East Asia, composed of many countries at different levels of political and economic development, is still far away from becoming a single community or a free trade area. Bilateral FTAs are instead drawing 
much attention from regional countries, and they have the potential to lay the ground for economic integration in the whole East Asian region.

This paper provides an analytical framework to evaluate FTA partners, upon which the South Korean government can design a FTA strategy. A rational strategy is necessary for South Korea to position itself at the center of the burgeoning East Asian regionalism. Income level and relative power of FTA partners are the two independent variables that determine the nature of the FTA agreement. As a middle-income country with little leverage against trading partners, this paper concludes, South Korea will get the maximum benefits by forming FTA with advanced, powerful economies like Japan and the United States. This paper cautions the South Korean government not to rush in for a FTA with China, a developing major power.

Joining an economic bloc is one thing, and harvesting maximum economic benefits is quite another. Liberalizing reforms are imperative for South Korea to stay competitive in a rapidly globalizing world. South Korea may do without bilateral FTAs as long as it can carry out unilateral liberalization. The South Korean economy, however, cannot do without domestic reforms even if it pursues an active FTA policy. Shallow integration that requires only cosmetic reforms will not help South Korea, which is suffering from domestic rigidity, systemic inefficiency, and low credibility among foreign investors toward its economic policy. Reform is an imperative for South Korea irrespective of its strategy toward FTA or regional integration. 


\section{References}

Baldwin, Richard E.. "A Domino Theory of Regionalism," in Richard E. Baldwin, Pertti Haaparanta, and Jaakko Kiander, eds., Expanding Membership of the European Union, Cambridge: Cambridge University Press, 1995.

Bowles, Paul. "Asia's Post-Crisis Regionalism: Bringing the State Back in, Keeping the (United) States Out," Review of International Political Economy, 9:2 (May 2002). Choi, Young Jong and James A. Caporaso. "Comparative Regional Integration," in Walter Carlsnaes, Thomas Risse, and Beth Simmons, eds., Handbook of International Relations, California: Sage Publications, 2002.

Choi, Young Jong and Nae Young Lee. "A Comparative Study of Regionalism in East Asia and the Americas," Asian Perspective, $26: 3$ (2002)

Chung, Inkyo. "Korea's FTA Policy: Focusing on Bilateral FTAs with Chile and Japan," Discussion Paper 02-02, Seoul: Korean Institute for International Economic Policy, 2002 ,

Dieter, Heribert and Richard Higgott. "Exploring Alternative Theories of Economic Regionalism: From Trade To Finance in Asian Co-Operation?", Review of International Political Economy, 10:3 (August 2003).

Evans, Paul. "East Asian Regionalism: Supplement or Alternative to an American-Centered Pacific Order?", in Proceeding for Annual International Conference (Building an East Asian Community: Visions and Strategies). Seoul: Asiatic Research Center, 2002.

Goldstein, Judith, Miles Kahler, Reober 0. Keohane, and Anne-Marie Slaughter. "Introduction: Legalization and World Politics," International Organization, 54:3 (Summer 2000).

Hansen, Roger D.. "Regional Integration: Reflections on a Decade of Theoretical Efforts," International Organization, 21:2 (1969).

Helleiner, Eric. State and The Emergence of Global Finance: From Bretton Woods to the 1990s. Ithaca: Cornell University Press, 1994.

Higgott, Richard. "The Asian Economic Crisis: A Study in the Politics of Resentment," New Political Economy, 4:1(1998).

Hirschman, Albert O.. National Power and the Structure of Foreign Trade. Berkeley: University of California Press, 1980.

Kajita, Takehiko. "Japan's new ASEAN policy comes as China rises," The Japan Times, January 15, 2002.

Keohane, Robert 0 . and Joseph Nye. Power and Interdependence. Harper Collins 
Publishers, 1989.

Lee, Chang-kyu. "Economic Relations between South Korea and China," World Economy (The Korea Economic Institute, Washington DC: 2004).

Martin, Lisa L. and Beth A. Simmons. "Theories and Empirical Studies of International Institutions," in Peter J. Katzenstein, Robert O. Keohane, and Stepan D. Krasner, eds., Exploration and Contestation in the Study of World Politics. Cambridge: The MIT Press, 1999.

MOFA (Japan's Ministry of Foreign Affairs). Japan's FTA Strategy (Summary, October 2002), http://www.mofa.go.jp/policy/economy/fta/strategy0210.html.

Pempel, T. J., ed. The Politics of the Asian Economic Crisis. Cornell University Press, 1999.

Ravenhill, John. "A three bloc world? The new East Asian regionalism," International Relations of the Asia-Pacific, 2 (2002).

Schiff, Maurice and L. Alan Winters. Regional Integration and Development. Washington DC: World Bank, 2003.

Sheen, Seongho. "Tilting toward the Dragon: South Korea's China Debate," Special Assessment: Asia's China Debate (Asia-Pacific Center for Security Studies, December 2003).

Snyder, Scott. "The Insatiable Sino-Korean Economic Relationship: Too Much for Seoul to Swallow?", Comparative Connection (CSIS Pacific Forum, 3rd quarter 2000).

Stubbs, Richard. 2002. "ASEAN Plus Three: Emerging East Asian Regionalism?", Asian Survey, vol. XLII, no.3 (May/June).

The East Asian Study Group. The Final Report of the East Asian Study Group, November 2002.

World Bank, Trade Blocs. New York: Oxford Press, 2000. 